\title{
The Chemical Composition of Winter Fogs at São Paulo Highway Sites
}

\author{
Pérola C. Vasconcellos, ${ }^{*, a}$ Fábio L. T. Gonçalves, ${ }^{b}$ Simone G. Avila, ${ }^{a}$ Vitor K. Censon ${ }^{b}$ \\ and Heidi Bauer ${ }^{\dagger, c}$ \\ ${ }^{a}$ Instituto de Química, Universidade de São Paulo, Av. Lineu Prestes 748, \\ 05508-000 São Paulo-SP, Brazil \\ ${ }^{b}$ Instituto de Astronomia, Geofísica e Ciências Atmosféricas, Universidade de São Paulo, \\ Rua do Matão 1226, 05508-090 São Paulo-SP, Brazil \\ 'Institute for Chemical Technologies and Analytics, University of Technology, \\ Getreidemarkt 9/164, 1060 Vienna, Austria
}

\begin{abstract}
Radiation and advection fogs were characterized at two sites nearby important roads next to São Paulo City, Brazil. Water-soluble ions, monosaccharides, other sugars and organic and elemental carbon (OC and EC) were determined. Both sites present a high number of fog events with mainly radiation fogs causing visibility problems to the automotive traffic (Castello Branco and Raposo Tavares roads). Samples were collected in nine events in 2009 and ten events in 2010, during wintertime. Two radiation and advection fog events have been herein presented. The radiation fog occurred in 2009 at Castello Branco Road (CBR), presented the highest concentration of pollutants comparing to all other events. The most abundant species are associated with biomass landfill and fossil fuel burning. Locally, the region has a strong impact by the fertilizer industries and traffic of heavy vehicles. The second most polluted event occurred also in 2009 at CBR, an advection fog presented species attributed to soil resuspension and anthropogenic emissions. The results are compared with rainwater composition studies.
\end{abstract}

Keywords: fog water, air pollution, industrial pollution, fog composition

\section{Introduction}

Fogs can affect the air pollution and human activities by different mechanisms. They cause limited visibility, which will affect driving conditions or airport activities. Moreover, they can affect local air quality by concentrating chemicals in small fog droplets, influencing the composition of the atmosphere by acting as a medium for chemical reactions or removing pollutants from the atmosphere through deposition processes.

Fog chemistry has been observed since the beginning of the last century with more intense studies at the end of the 1900 s because of the increased interest in acid fog and its impact on human health and materials. ${ }^{1-3}$ In recent years, the focus shifted from fog acidity studies towards organic matter in fogs and on how fog affects the secondary organic

\footnotetext{
*e-mail: perola@iq.usp.br
}

†n memoriam aerosol formation. ${ }^{4}$ Amato et al. ${ }^{5}$ suggested the possibility of bacterial activity in fogs and clouds.

Most of fog studies occurred in Europe, particularly in the Po Valley, ${ }^{6}$ and in North America, ${ }^{7}$ especially in the Central Valley of California. ${ }^{2,8}$ In recent years, the observational database became substantially more diverse geographically with an increasing number of fog observation studies in Asia. ${ }^{9} 10$ However, some areas of the world like Africa and South America have only reported a very limited amount of fog studies, especially in urban areas. In large urban environments like the São Paulo metropolitan area and surroundings, fogs and fog processing of atmospheric compounds has a profound impact on the visibility. Still to date only very limited information on precipitation chemistry is available. ${ }^{11-13}$

The formation and microphysical properties of fogs can be influenced by the abundance of water vapor, local environmental conditions and the occurrence of pollutants, especially those in the particle phase. The presence of high numbers of cloud condensation nuclei (CCN) can influence 
the size distribution of the fog droplet, optical density, and rate of water removal by droplet sedimentation. ${ }^{2}$ Those $\mathrm{CCN}$ can be produced by industries, vehicular exhaustion or other anthropogenic sources, affecting the local fog formation.

The droplets that make up a fog can interact with trace species in the atmosphere. The accumulated solute species may participate in aqueous phase reactions, some of which can generate secondary inorganic mass that can remain as residual particles after evaporation. ${ }^{14}$

Many organic compounds were found in the fog samples: volatile carboxylic acids (acetic and formic acids) and mostly aldehydes. ${ }^{715}$ Chapelon and Loones ${ }^{16}$ reported that although only $10 \%$ of overall traffic occurs at night, one third of accidents and $50 \%$ of fatalities occurred during this period. According to this study, foggy conditions, in France, are associated with $2 \%$ of traffic-related deaths during the last ten years. Because fog events represent a real peril for traffic, highway managers are especially concerned about nighttime conditions that can give rise to dense fog formation.

In this study, observations on fogs and fog composition (water soluble ions, monosaccharides, other sugars, organic (OC) and elemental carbon (EC)) in the São Paulo motorways, nearby the São Paulo metropolitan area (SPMA), are presented.

Fog samples were collected at two sites nearby important roads surrounding the SPMA, in São Paulo State, Brazil. Fog type, meteorological conditions, fog chemistry, composition and sources are discussed. Since no other work on fog water study has been evaluated in São Paulo State, the results are compared with rainwater composition studies. The results can be useful to establish public politics, to the motorway managers and local government aiming the protection of people on the roads. In addition, it will be important to monitor the local air quality highly influenced by industrial emissions and biomass burning.

\section{Experimental}

\section{Sampling procedures}

Fog samples were collected at two sites using Caltech Active Strand Cloudwater Collectors (CASCC). ${ }^{17}$ The CASCC collects fog droplets by inertial impaction on 6 inclined rows of $508 \mu \mathrm{m}$ Teflon ${ }^{\circledR}$ strands. The airflow rate through the collector is $24 \mathrm{~m}^{3} \mathrm{~min}^{-1}$ and the $50 \%$ lower size cut is $3.5 \mu \mathrm{m}$ diameter. Collected droplets coalesce and run down the strands, aided by gravity and aerodynamic drag, into a Teflon ${ }^{\circledR}$ sample trough. Fog water was collected through a Teflon ${ }^{\circledR}$ tube into a polyethylene sample bottle. The collectors were cleaned prior to each event, using deionized water. The collectors worked manually when fogs events were observed between 3:00 a.m. and 8:00 a.m. local time.

Weather and climate data are based on Weather Station (IAG) located in the campus of the University of São Paulo.

\section{Sampling site characteristics}

Samples were collected at the Raposo Tavares Road (RTR) and at Castello Branco Road (CBR). Both sites are located approximately $50 \mathrm{~km}$ from the São Paulo City Center. RTR is $654 \mathrm{~km}$ and CBR is $315 \mathrm{~km}$ long.

The RTR site is surrounded by a rural landscape (fisheries and agricultural activities) and presents low traffic ( 8,000 vehicles per day, which 800 are trucks). The CBR site is characterized by larger traffic volumes (four times higher than the traffic at RTR with 33,000 vehicles, which 9,000 are trucks) with industries (steel, dye and lime companies) in the surroundings. Additionally, pulp and fertilizer industries are also present on this road.

\section{Analytical procedures}

\section{Water-soluble ions}

Fog samples were filtered using $0.45 \mu \mathrm{m}$ pore size membranes (Whatman plc, Middlesex, UK), and stored in clean polyethylene bottles. After $\mathrm{pH}$ measurement, ionic species were determined by ion chromatography (Metrohm AG, Herisau, Switzerland) with chemical suppression and conductivity detection. For anion detection $\left(\mathrm{F}^{-}, \mathrm{Cl}, \mathrm{Br}\right.$, $\mathrm{NO}_{3}{ }^{-}, \mathrm{SO}_{4}{ }^{2-}$ ), samples were injected via a $20 \mu \mathrm{L}$ loop and eluted over a Metrosep A Supp 5 250/4.0 mm analytical column (Metrohm, Herisau, Switzerland). A mixture of $1.0 \mathrm{mmol} \mathrm{L}^{-1} \mathrm{NaHCO}_{3}$ and $3.2 \mathrm{mmol} \mathrm{L}^{-1} \mathrm{Na}_{2} \mathrm{CO}_{3}$ was used as eluent. The system was regenerated using a solution of $50 \mathrm{mM} \mathrm{H}_{2} \mathrm{SO}_{4}$ pumped through a suppressor unit simultaneously with deionized water. A Metrosep C2-150 150/4.0 mm analytical column (Metrohm, Herisau, Switzerland) was used for cation detection $\left(\mathrm{K}^{+}, \mathrm{NH}_{4}^{+}\right.$, $\mathrm{Ca}^{2+}, \mathrm{Mg}^{2+}$ and $\left.\mathrm{Na}^{+}\right)$and the eluent used was a solution of $2.7 \mathrm{mmol} \mathrm{L}^{-1}$ oxalic acid in isocratic mode. The inorganic anions recovery were from 109 to $118 \%$, from 80 to $101 \%$ for cations and from 87 to $107 \%$ for organic anions. The limits of detection (LOD, $\mathrm{S} / \mathrm{N}=4$ ) ranged between $0.023-0.085 \mathrm{mg} \mathrm{L}^{-1}$ (inorganic anions), 0.046-0.157 $\mathrm{mg} \mathrm{L}^{-1}$ (cations) and $0.004-0.010 \mathrm{mg} \mathrm{L}^{-1}$ (organic acids). Blank values were subtracted from sample determinations. ${ }^{18}$

\section{Saccharides}

The analysis was performed using a Dionex ICS-3000 system column (Dionex, Sunnyvalle, USA) consisting of 
a quaternary pump and degasser, column compartment, electrochemical detector and gold electrode, and eluent organizer units. The waveform used for pulsed amperometric detection was the standard quadruple potential for carbohydrate analysis (Dionex Technical Note 21). ${ }^{19}$ The separation was carried out on a Dionex CarboPac MA1 column $(4 \times 250 \mathrm{~mm}$, Thermo Fisher, Waltham, USA) with a guard column $(4 \times 50 \mathrm{~mm})$ at room temperature. This column is suited for separation of reduced monosaccharides. UP (ultrapure) water (eluent A) and $1.0 \mathrm{~mol} \mathrm{~L}^{-1}$ sodium hydroxide (eluent B) solution were used for the separation. The UP water was purged with helium for a minimum of $15 \mathrm{~min}$ to remove dissolved gases, particularly carbon dioxide. To prepare $1.0 \mathrm{~mol} \mathrm{~L}^{-1}$ sodium hydroxide eluent, $104.6 \mathrm{~mL}$ of $50 \%(\mathrm{~m} / \mathrm{m})$ sodium hydroxide solution was diluted to $2 \mathrm{~L}$. The eluent flow rate was $0.4 \mathrm{~mL} \mathrm{~min}^{-1}$. The sample injection loop was $25 \mathrm{~mL}$. All eluent reservoirs were blanketed by helium to minimize carbon dioxide contamination from the air. Instrumental controls, data acquisition, and chromatographic integration were performed using Dionex Chromeleon software. ${ }^{20}$

The limit of detection was determined as the minimum concentration that was visible on the chromatogram and produced a peak height at least three times the signal to noise ratio. For galactosan and fructose, the minimum visible concentrations were taken as LOD values because they were much higher than $\mathrm{S} / \mathrm{N}=3$. The LOD values were in the range of $0.002-0.08 \mathrm{mg} \mathrm{L}^{-1}$ corresponding to $0.1-2 \mathrm{ng}$ absolute analyte mass injected using a $25 \mathrm{~mL}$ loop.

Determination of total carbon (TC), elemental carbon (EC) and organic carbon (OC) in liquid samples

For determination of TC in liquid samples, a commercial instrument (GOTOC 100, Gröger \& Obst $\mathrm{GmbH}$, Wolfratshausen, Germany) modified to a flow injection system was used. Catalytic combustion takes place at $850{ }^{\circ} \mathrm{C}$. The evolving $\mathrm{CO}_{2}$ is determined with a nondispersive infrared (NDIR) detector. To eliminate the influence of dissolved $\mathrm{CO}_{2}$, the samples were acidified with nitric acid $\left(100 \mu \mathrm{L} 1 \mathrm{~mol} \mathrm{~L}^{-1} \mathrm{HNO}_{3} \mathrm{~mL}^{-1}\right)$, stripped with pure $\mathrm{N}_{2}$, and then injected into the sample loop $(300 \mu \mathrm{L})$. Standard solutions for calibration were prepared from phthalic acid (p.a., Merck, Darmstadt, Germany). The limit of quantification (6s of the multiple $(n=9)$ injection of demineralized water) was $0.4 \mu \mathrm{g} \mathrm{C} \mathrm{mL}^{-1}$, corresponding to an absolute limit of quantification of $0.12 \mu \mathrm{g}$ C. More details are given by Bauer et al..$^{21}$ Black carbon (BC) was again determined with the integrating sphere. OC was calculated as TC - BC.

\section{Hysplit analysis}

Hysplit (hybrid single-particle Lagrangian integrated trajectory) data analyses, from Draxler, ${ }^{22}$ were performed in order to identify the air masses trajectories. The resulting figures show the origins of air masses at three different levels $(500,1000$ and $1500 \mathrm{~m})$ for fog events collected.

\section{Overall meteorological conditions and fog occurrence}

The winter of 2009 was wetter than the average due to the El Niño phenomenon, ${ }^{23}$ with several record rainfall events between July and October in the SPMA. Rainfall totaled approximately $200 \mathrm{~mm}$ in July, four times higher than usual and this anomaly extended through the following months. The higher water vapor content in the atmosphere could increase the likelihood of fog events, but low temperatures are also important for radiation fog formation. Minimum temperatures were approximately $1{ }^{\circ} \mathrm{C}$ higher than the average (over $11^{\circ} \mathrm{C}$ ), decreasing the possibility of fog formation. Radiation fog events, in the study region, are generally favored during periods characterized by high-pressure systems (anticyclonic) with clear night skies, quick fall of air temperature and no wind. These conditions were less frequent, probably due to the prevailing El Niño conditions, where the low pressure system may increase. On the other hand, advection fog events are characterized by low-pressure systems (cyclonic), cloudy and sometimes with rain and drizzle, and with wind blowing from the sea side, bringing humidity and without a quick air temperature fall (due to the clouds).

On the other hand, the winter of 2010 was characterized by drier periods in July and wetter periods in August. The weather station recorded that July was warmer, with minimum temperatures over $1.6{ }^{\circ} \mathrm{C}$ above average (over $11^{\circ} \mathrm{C}$ ). However, there were wet periods during July as well as dry periods in August. The samples were collected during the fog events in the wet periods of July which presented advection fogs, mixed with rain and drizzle.

\section{Results and Discussion}

\section{Species concentration}

Table 1 presents the chemical composition of the fog samples collected at both sites in 2009 and 2010. At CBR, with more intense traffic and more industries, water-soluble total ions concentrations (TIC) were

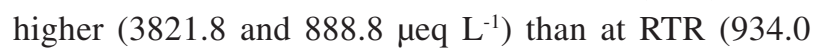
and $619.7 \mu \mathrm{eq} \mathrm{L} \mathrm{L}^{-1}$ ).

In 2009, the major ionic species at $\mathrm{CBR}$ were $\mathrm{K}^{+}$ (average $1647 \mu \mathrm{eq} \mathrm{L}{ }^{-1}$ ), $\mathrm{Cl}^{-}$(average $610 \mu \mathrm{eq} \mathrm{L} \mathrm{L}^{-1}$ ) and $\mathrm{NH}_{4}^{+}$ (average $\left.483 \mu \mathrm{eq} \mathrm{L}{ }^{-1}\right)$. At RTR were $\mathrm{Ca}^{2+}\left(183 \mu \mathrm{eq} \mathrm{L} \mathrm{L}^{-1}\right), \mathrm{NH}_{4}^{+}$ 
Table 1. Average concentration of water-soluble ions found in the fog samples collected in Castello Branco Road (CBR) and Raposo Tavares Road (RTR) in the years 2009 and 2010

\begin{tabular}{|c|c|c|c|c|}
\hline & CBR-2009 & RTR-2009 & CBR-2010 & RTR-2010 \\
\hline \multicolumn{5}{|c|}{ Inorganic anion / $\left(\mu \mathrm{eq} \mathrm{L}^{-1}\right)$} \\
\hline $\mathrm{F}^{-}$ & 434 & 15 & 11 & 5.4 \\
\hline $\mathrm{Cl}^{-}$ & 610 & 95 & 270 & 150 \\
\hline $\mathrm{NO}_{2}^{-}$ & 111 & 37 & 14.4 & 38 \\
\hline $\mathrm{Br}^{-}$ & 0.8 & 1.0 & 1.3 & BDL \\
\hline $\mathrm{NO}_{3}^{-}$ & 41 & 60 & 12 & 16 \\
\hline $\mathrm{PO}_{4}^{3-}$ & 1.7 & 6 & 4 & 6.3 \\
\hline $\mathrm{SO}_{4}^{2-}$ & 336 & 138 & 36 & 36 \\
\hline \multicolumn{5}{|c|}{ Organic acid / $\left(\mu \mathrm{eq} \mathrm{L} \mathrm{L}^{-1}\right)$} \\
\hline Acetic & 5.1 & 8 & BDL & BDL \\
\hline Formic & 4.8 & 6 & 0.4 & BDL \\
\hline Oxalic & 2.5 & 6 & 2.0 & 1.7 \\
\hline Fumaric & 0.9 & 1.0 & $\mathrm{BDL}$ & BDL \\
\hline Succinic & 1.5 & 1.0 & 3.0 & BDL \\
\hline \multicolumn{5}{|c|}{ Cation / $\left(\mu \mathrm{eq} \mathrm{L} \mathrm{L}^{-1}\right)$} \\
\hline $\mathrm{Na}^{+}$ & 5 & 80 & 35 & 11.4 \\
\hline $\mathrm{NH}_{4}^{+}$ & 483 & 157 & 21 & 80 \\
\hline $\mathrm{K}^{+}$ & 1647 & 58 & 238 & 178 \\
\hline $\mathrm{Mg}^{2+}$ & 5 & 82 & 28 & 11.6 \\
\hline $\mathrm{Ca}^{2+}$ & 133 & 183 & 211 & 86 \\
\hline
\end{tabular}

BDL: below detection limit.

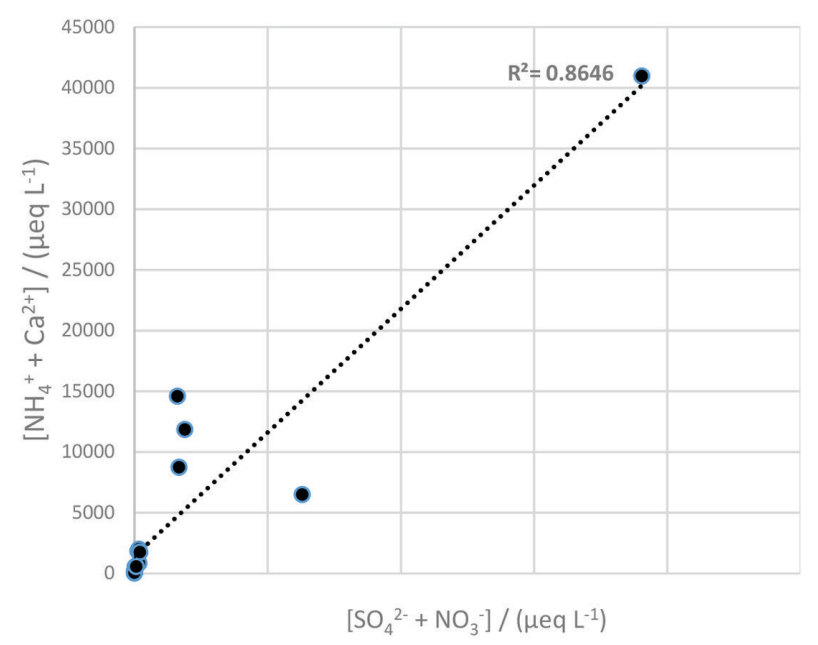

Figure 1. Correlation between the concentrations of the acidic inputs (nitrate plus sulfate) with neutralizing species.

(157 $\mu$ eq $\left.\mathrm{L}^{-1}\right)$ and $\mathrm{SO}_{4}{ }^{2-}\left(138 \mu\right.$ eq $\left.\mathrm{L}^{-1}\right)$. In 2010 the major ionic species at both sites were $\mathrm{Cl}^{-}, \mathrm{K}^{+}$and $\mathrm{Ca}^{2+}$.

In 2009 , potassium made up $43 \%$ of the total ion concentration at CBR and chloride $30 \%$ in 2010 . At RTR, calcium made up 20\% (2009) and potassium 29\% in 2010. Soil components and secondary species were ubiquitous at these sites, followed by potassium that could also have come from biomass burning occurred in the vicinities.
Ammonium and sulfate often seem to be the most abundant species in other studies. ${ }^{7,14}$

In previous fog studies, ${ }^{14}$ in California, ammonium $\left(1066 \mu \mathrm{mol} \mathrm{L}^{-1}, 41 \%\right)$ was the most abundant ionic species followed by sulfate $(22 \%)$, calcium $(12 \%)$ and nitrate (7.7\%). In China, fog samples collected in the Nanjing area, at a site close to pollution influenced by petrochemical factories, nitrogenous fertilizer plant, highways and other sources, presented concentration of $6969 \mu \mathrm{eq} \mathrm{L}^{-1}$ for sulfate and $6654 \mu \mathrm{eq} \mathrm{L} \mathrm{L}^{-1}$ for ammonium. ${ }^{24}$ These two ions made up more than $60 \%$ of the total ion concentrations.

In the present study, ions concentrations are highly variable and differences can reach 2 orders of magnitude between two events at the same site.

Calcium has been one of the most abundant species in these samples. São Paulo City is $80 \mathrm{~km}$ far from the sea and atmospheric samples are often impacted by the sea salt. In addition, building construction can contribute to build up calcium. To check if the fog events might be affected by sea salt, non-sea salt calcium concentration was calculated (nss- $\mathrm{Ca}^{2+}$ ) using the equation by Błaś et al.:25

$\left[\right.$ nss- $\left.\mathrm{Ca}^{2+}\right]=\left[\mathrm{Ca}^{2+}\right]-0.0373\left[\mathrm{Na}^{+}\right]$

where $\left[\right.$ nss- $\left.\mathrm{Ca}^{2+}\right],\left[\mathrm{Na}^{+}\right],\left[\mathrm{Ca}^{2+}\right]$ are concentrations of the species.

At both sites, more than $95 \%$ of calcium origin appeared to be predominantly from soil resuspension.

Studies on fog composition are scarce in São Paulo. Yet, some studies occurred on rainwater composition. In the 80's, rainwater was collected on campus of the University of São Paulo during the dry and wet seasons. The major species were calcium, nitrate, sulfate and ammonium; the highest concentrations were found in the dry period due to meteorological conditions. ${ }^{26}$

In the same way, Oliveira et al. ${ }^{13}$ collected rainwater samples at a sugarcane burning site (Araraquara City, $300 \mathrm{~km}$ from São Paulo) and observed the major ions were also calcium, ammonium and nitrate; they observed that the concentrations were influenced by seasonal variation due to the agricultural activities.

Other species were found in the fog water samples in lower concentrations at both sites: oxalate (2.5 and $6 \mu$ eq $\mathrm{L}^{-1}$ ), fumarate (over $1.0 \mu \mathrm{eq} \mathrm{L}^{-1}$ ), succinate (over $1.5 \mu \mathrm{eq} \mathrm{L}^{-1}$ ), formate (from 0.4 to $6.0 \mu \mathrm{eq} \mathrm{L}^{-1}$ ) and acetate (from 5.1 to $8 \mu \mathrm{eq} \mathrm{L}^{-1}$ ).

Acetate and formate are ubiquitous in urban atmospheres. Their origin is mostly attributed to anthropogenic emissions and their concentrations can be increased due to photochemical reactions and vegetation contribution. Higher acetate concentrations rather than formate in the 
atmosphere may indicate strong vehicular emissions influences. Previous studies in São Paulo City showed that approximately $98 \%$ of the total acetic and formic acids found in aerosols were in the gas-phase and the gas-aerosol equilibrium was influenced by high relative humidity. ${ }^{27}$ In 2009, they were the most abundant organic acids followed by oxalate. Kawamura and Kaplan ${ }^{28}$ mentioned reactions forming oxalate at urban sites, but vehicle emissions, biogenic activity and biomass burning have also been proposed. The main air pollution source in the metropolitan area of São Paulo has been attributed to vehicular emission. The addition of ethanol to motor vehicle fuels reduces carbon monoxide, but increases aldehyde emissions (especially acetaldehyde), inducing a unique photochemical smog problem. Besides these different fuels, biodiesel has been used and consequences in the air pollution has recently been studied. ${ }^{29}$

Succinic and fumaric acids presented low concentrations. Dicarboxylic acids are important since their hygroscopicity property can affect cloud formation and global radiation reaching the ground. ${ }^{30}$

Sulfate/nitrate average ratios ranged from 0.8 to 3.0. One sample presented this ratio equal 8.1. High ratios are found in atmospheric samples due to the nitrate volatilization that occurs under high temperatures. ${ }^{31}$

Concentrations of the acidic inputs (nitrate plus sulfate) were correlated with the sum of ammonium and calcium (coefficient of determination $\left(\mathrm{R}^{2}\right)=0.8646$ ) in the fog samples. It indicates that calcium was also important to neutralize nitrate and sulfate (Figure 1).

In fact, in all samples collected, only two samples presented higher concentration of ammonium than the sum of nitrate and sulfate. For these samples, organic acids must be important species for neutralization of the atmosphere.

Sulfate in fog water derives from aerosol scavenging or in situ oxidation of dissolved sulfur dioxide, and nitrate from both the scavenging of aerosol nitrate and the uptake of gaseous nitric acid. ${ }^{2}$

The average and range of the balance between total anions/total cations are the following: at CBR 2009 is
1.1 (1-1.3), RTR 2009 is 1.7 (0.7-2.7), at CBR 2010 is $0.54(0.41-0.79)$ and at RTR 2010 is $0.67(0.63-0.71)$. The 2009 samples presented higher ratios than 2010 . Unmeasured organic acids contributed to these results.

Other correlations were also observed between sulfate and chloride and they were strong (correlation coefficient $(\mathrm{R}) \geq 0.98$ ) at both sites, except at RTR in 2010. Sulfate in São Paulo atmosphere is often attributed to fossil fuel burning and chloride, to landfill burning or marine plumes. ${ }^{32}$

As expected, calcium and magnesium, soil components also presented strong correlation $(\mathrm{R} \geq 0.88)$ and sulfate and ammonium presented moderate correlation $(\mathrm{R} \geq 0.55)$ in 2009; between sulfate and nitrate, the correlations were strong ( $\mathrm{R} \geq 0.99)$, except at $\mathrm{CBR}$ in 2009; ammonium and chloride presented good correlations $(\mathrm{R} \geq 0.52)$, except at RTR in 2010. Chloride and potassium also presented strong correlations at both sites and campaigns $(\mathrm{R} \geq 0.99)$. Potassium is a crustal species that can be found at sites with agricultural influences and on roads, suspended by vehicles. Fertilizers industries for soil liming in this region may enhance potassium chloride concentration in the fog samples. Nitrate and potassium presented good correlation (R ca. 0.96) at RTR (2009) and at CBR (2010) samples and it is likely that they have the same source.

Potassium in São Paulo atmosphere is often attributed to the contribution of sugarcane burning often observed in the state during wintertime, ${ }^{18}$ mainly when it comes well correlated with levoglucosan.

In this work, levoglucosan and its isomers were found only in four samples in low levels (from 0.001 to $0.014 \mu \mathrm{eq} \mathrm{L}^{-1}$ ). Table 2 presents the monosaccharides concentrations.

Other sugars were found in low concentration in

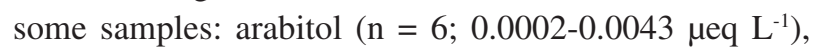
mannitol $\left(\mathrm{n}=6\right.$; 0.0002-0.0046 $\left.\mu \mathrm{eq} \mathrm{L^{-1 }}\right)$, trehalose $\left(\mathrm{n}=2 ; 0.0002-0.0006 \mu\right.$ eq L $\left.\mathrm{L}^{-1}\right)$, glucose $(\mathrm{n}=6$; $0.0002-0.0048 \mu$ eq L $\left.\mathrm{L}^{-1}\right)$, fructose $\left(\mathrm{n}=1 ; 0.0013 \mu \mathrm{eq} \mathrm{\textrm {L } ^ { - 1 }}\right)$ and galactose $\left(n=1 ; 0.0002 \mu\right.$ eq $\left.\mathrm{L}^{-1}\right)$.

Bauer et $a l .{ }^{33}$ suggested that mannitol and arabitol concentrations are correlated to the fungal spore counts

Table 2. Average concentration of monosaccharides, OC and EC found in the fog samples collected in Castello Branco Road (CBR) and Raposo Tavares Road (RTR) in the years 2009 and 2010

\begin{tabular}{|c|c|c|c|c|}
\hline & CBR-2009 & RTR-2009 & CBR-2010 & RTR-2010 \\
\hline Levoglucosan / $\left(\mu \mathrm{eq} \mathrm{L} \mathrm{L}^{-1}\right)$ & 0.328 & 0.597 & BDL & BDL \\
\hline Mannosan / $\left(\mu\right.$ eq $\left.\mathrm{L}^{-1}\right)$ & 0.030 & 0.113 & BDL & BDL \\
\hline Galactosan / ( $\mu$ eq L $\left.{ }^{-1}\right)$ & 0.020 & 0.010 & BDL & BDL \\
\hline $\mathrm{OC} /\left(\mu \mathrm{g} \mathrm{mL}^{-1}\right)$ & 2.6 & 4.9 & 2.3 & 1.5 \\
\hline $\mathrm{EC} /\left(\mu \mathrm{g} \mathrm{mL} L^{-1}\right)$ & 0.4 & 0.5 & 0.45 & 0.1 \\
\hline
\end{tabular}

BDL: below detection limit; OC: organic carbon; EC: elemental carbon. 
in coarse particulate matter $\left(\mathrm{PM}_{10}\right)$. These polyols are common storage substances in fungal spores. Mannitol, common in fungi and abundant in algae, was detected in more than 70 plant families. ${ }^{33,34}$ These alcohol sugars, glucose and trehalose are abundant in atmospheric coarse particulate matter. Likely, they are derived from primary biological particles. ${ }^{35}$

Organic carbon (OC) and elemental carbon (EC) were found in the samples ranging from 1.5 to $4.9 \mu \mathrm{g} \mathrm{mL}^{-1}$ and from 0.03 to $0.53 \mu \mathrm{g} \mathrm{mL}^{-1}$, respectively (Table 2 ). In the atmosphere, the $\mathrm{OC}$ originates from both direct emissions of particles and atmospheric transformation of organic gases. Secondary OC is generated by the condensation of low vapor pressure products. On the other hand, EC is emitted directly to the atmosphere. ${ }^{36}$ In Brazilian atmospheric samples, biomass burning can contribute to EC content. The contribution of OC was higher than $\mathrm{EC}$ in all samples; thus it can indicate the influences of local vehicular traffic. However, the relative contribution of EC associated to the presence of levoglucosan and its isomers may indicate long-range transport of air masses and influence of biomass burning.

\section{Advection vs. radiation fog events}

The data resolved by fog type shows substantial differences in the species concentrations (Figure 2). The $\mathrm{pH}$ observations are only available for advection fogs and ranged from 5.03 to 7.76 .
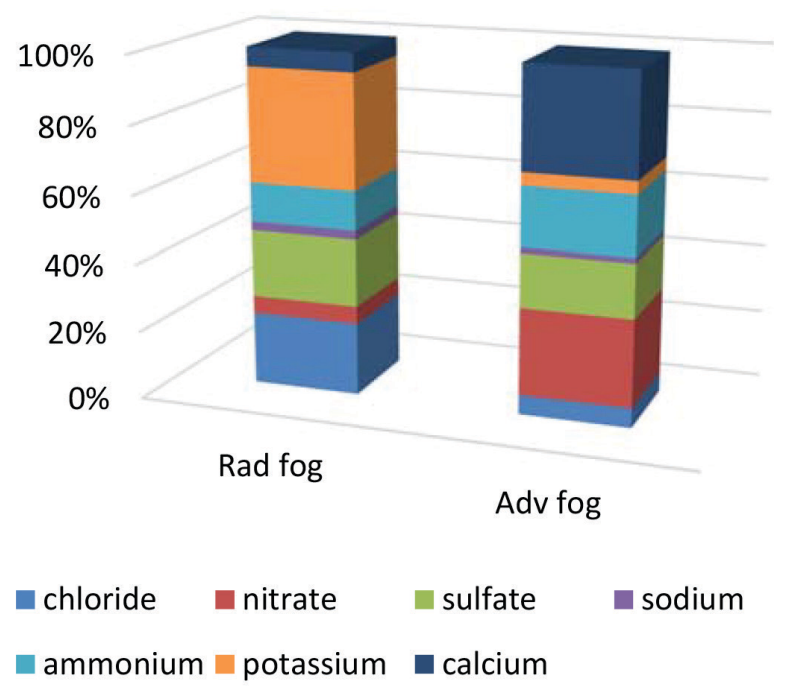

Figure 2. Composition of radiation (Rad) and advection (Adv) fogs of the samples collected in 2009.

Some patterns emerge when considering the relative composition of the fog events based on average concentrations by fog type and location of samples collected in 2009. The main ionic species in the radiation fog were $\mathrm{K}^{+}, \mathrm{Cl}^{-}$, and $\mathrm{SO}_{4}{ }_{4}^{2-}$. This fog composition is unusual, normally ammonium and nitrates are the dominant species in fog as reported elsewhere. ${ }^{7,14}$ A previous work ${ }^{37}$ on rainwater in São Paulo City, at a much-polluted site (center), showed the most abundant ions: ammonium, nitrate and acetate. On the other hand, advection fog presented $\mathrm{Ca}^{2+}, \mathrm{NO}_{3}{ }^{-}$and $\mathrm{SO}_{4}{ }^{2-} \cdot \mathrm{Ca}^{2+}$ presence coupled to high $\mathrm{pH}$ might be the indication of a soil contribution $\left(\mathrm{CaCO}_{3}\right)$. An important contribution of soil could come from local unpaved roads as well as activities on the road (unpaved streets are common in the vicinities of roads).

Between the fog events, a large difference in the species concentrations is observed. The radiation fogs presented much higher concentrations of the ionic species $\left(105952 \mu \mathrm{eq} \mathrm{L}^{-1}\right)$ than the advection fogs $\left(1763 \mu \mathrm{eq} \mathrm{L}^{-1}\right)$. Monosaccharides were present only in two samples of radiation fog, in low concentrations.

Figures $3 \mathrm{a}$ and $3 \mathrm{~b}$ present the air mass back trajectories calculated for the two days most polluted (May $1^{\text {st }}$ and September $\left.29^{\text {th }}, 2009\right)$. In the Figure $3 \mathrm{a}$, on May $1^{\text {st }}$, characterized by radiation fog, $96 \mathrm{~h}$ air masses came from Southwest Brazil, coming before from other South American countries (Argentina and Paraguay), while on September $29^{\text {th }}$, characterized by advection fog, the air masses came from the ocean, passing over polluted region where petrochemical derivatives are produced.

\section{Conclusions}

Fog water composition was investigated at two roadside sites in São Paulo State, where both sites experienced radiation as well as advection fog.

Two important events, for advection and radiation fog, are herein presented. The radiation fog occurred in 2009 at $\mathrm{CBR}$, presented the highest concentration of pollutants comparing with all events. The most abundant species were potassium, chloride and sulfate. These species are associated with biomass landfill and fossil fuel burning. Air mass trajectory indicated air masses coming from the Southwestern Brazil and other countries. Locally, the region has a strong impact by the fertilizer industries and big vehicles traffic.

The second most polluted event, an advection fog also at $\mathrm{CBR}$, presented higher concentration of calcium, nitrate and sulfate, species attributed to soil resuspension and anthropogenic emissions.

Levoglucosan and its isomers were present in few samples and is often attributed to biomass burning. Other sugars like arabitol, mannitol, trehalose, glucose, fructose and galactose indicated the presence of biogenic emissions. 

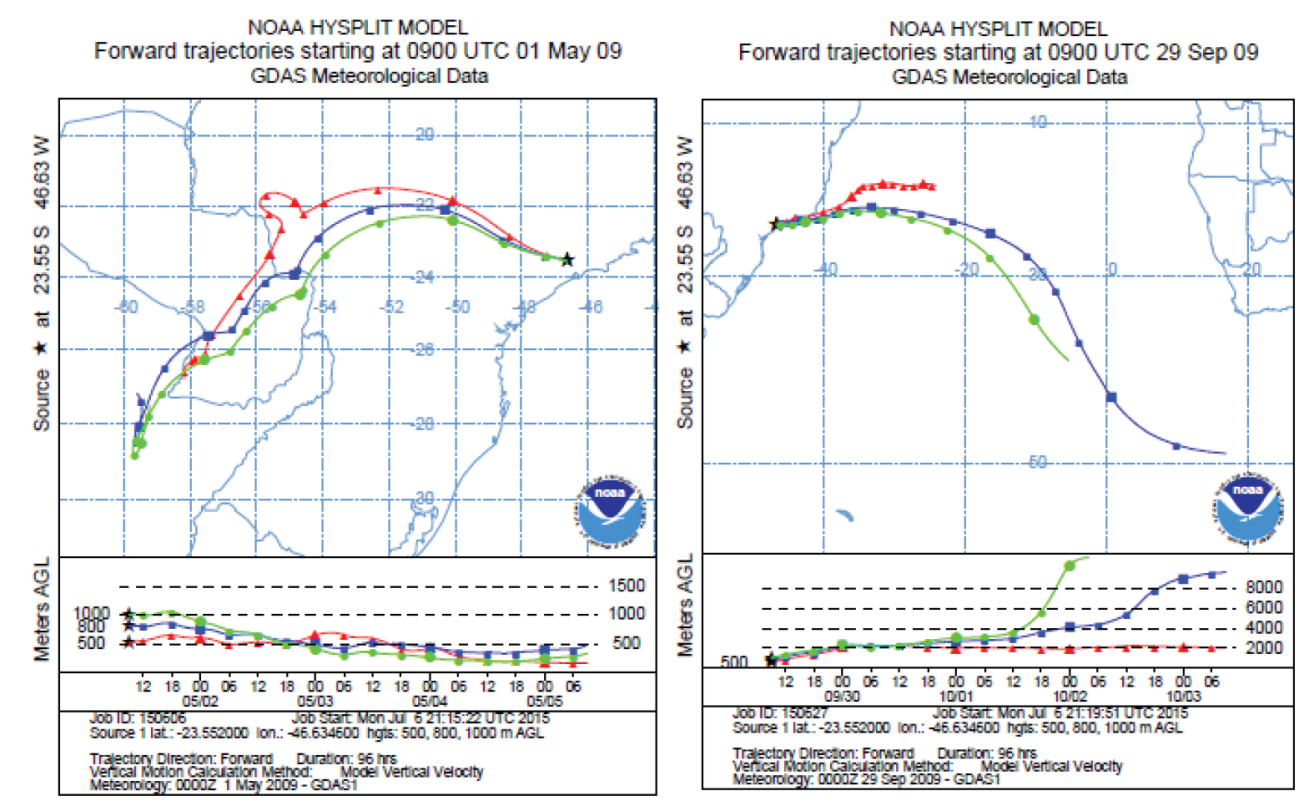

Figure 3. Air mass back trajectories calculated for the two most polluted days in 2009: (left) May $1^{\text {st }}$ and, (right) September $29^{\text {th }}$, at CBR site.

The contribution of OC was higher than EC in all samples; it indicates the influences of local vehicular traffic. However, the relative contribution of EC associated to the presence of levoglucosan and its isomers may indicate long-range transport of air masses and influence of the incomplete biomass burning.

Summarizing, the results highlighted the fact that there is a concentration of pollutants, particularly hygroscopic species at both sites. The study of these species is important to monitor the local air quality and the fog formation in the atmosphere of important roads surrounding São Paulo City.

\section{Acknowledgments}

The authors thank the financial agency of São Paulo State (FAPESP), CNPq grants (301784/2012-4) and INCT Energy and Environment.

\section{References}

1. Weathers, K. C.; Likens, G. E.; Bormann, F. H.; Bicknell, S. H.; Bormann, B. T.; Daube, B. C.; Eaton, J. S.; Galloway, J. N.; Keene, W. C.; Environ. Sci. Technol. 1988, 22, 1018.

2. Collett Jr., J. L.; Hoag, K. J.; Sherman, D. E.; Bator, A.; Richards, L. W.; Atmos. Environ. 1999, 33, 129.

3. Millet, M.; Sanusi, A.; Wortham, H.; Environ. Pollut. 1996, 94 , 345.

4. Herckes, P.; Valsaraj, K. T.; Collet Jr., J. L.; Atmos. Res. 2013, 132-133, 434.

5. Amato, P.; Parazols, M.; Sancelme, M.; Laj, P.; Mailhot, G.; Delort, A.-M.; FEMS Microbiol. Ecol. 2007, 59, 242.
6. Fuzzi, S.; Facchini, M.; Orsi, G.; Lind, J.; Wobrock, W.; Kessel, M.; Maser, R.; Jaeschke, W.; Enderle, K. H.; Arends, B. G.; Berner, A.; Solly, I.; Kruisz, C.; Reischl, G.; Pahl, S.; Kaminski, U.; Winkler, P.; Ogren, J. A.; Noone, K. J.; Hallberg, A.; Fierlinger-Oberlinninger, H.; Puxbaum, H.; Marzorati, A.; Hansson, H.-C.; Wiedensohler, A.; Sveningsson, I. B.; Martinsson, B. G.; Schell, D.; Georgii, H. W.; Tellus B 1989, 44, 448.

7. Raja, S.; Raghunathan, R.; Yu, X.-Y.; Lee, T.; Chen, J.; Kommalapati, R.; Murugesan, X.; Qingzhong, Y.; Valsaraj, T.; Collet Jr, J. L.; Atmos. Environ. 2008, 42, 2048.

8. Collett Jr., J. L.; Herckes, P.; Youngster, S.; Lee, T.; Atmos. Res. 2008, 87, 232.

9. Biswas, K. F.; Badar, M. G.; Husain, L.; Atmos. Environ. 2008, 42, 7775 .

10. Safai, P. D.; Kewat, S.; Pandithurai, G.; Praveen, P. S.; Ali, K.; Tiwari, S.; Rao, P. S. P.; Budhawant, K. B.; Saha, S. K.; Devara, P. C. S.; J. Atmos. Chem. 2008, 61, 101.

11. Lara, L. B. L. S.; Artaxo, P.; Martinelli, L. A.; Victoria, R. L.; Camargo, P. B.; Krusche, A.; Ayers, G. P.; Ferraz, E. S. B.; Mallester, M. V.; Atmos. Environ. 2001, 35, 4937.

12. Fornaro, A.; Gutz, I. G. R.; Atmos. Environ. 2006, 40, 5893.

13. Oliveira, P. L.; Figueiredo, B. R.; Cardoso, A. A.; J. Braz. Chem. Soc. 2012, 23, 2258.

14. Straub, D. J.; Hutchings, J. W.; Herckes, P.; Atmos. Environ. 2012, 47, 195.

15. Ervens, B.; Wang, Y.; Eagar, J.; Leaitch, W. R.; Macdonald, A. M.; Valsaraj, K. T.; Herckes, P.; Atmos. Chem. Phys. 2013, 13, 5117.

16. Chapelon, J.; Loones, F.; Analysis of Road Traffic Injury Accidents Occurring at Night and/or in Foggy Conditions; National Observatory for Road Safety, Paris, France, 2001. 
17. Demoz, B. B.; Collett Jr., J. L.; Daube Jr., B. C.; Atmos. Res. 1996, $41,47$.

18. Vasconcellos, P. C.; Souza, D. Z.; Ávila, S. G.; Araújo, M. P.; Naoto, E.; Nascimento, K. H.; Cavalcante, F. S.; dos Santos, M.; Smichowski, P.; Behrentz, E.; Atmos. Environ. 2011, 45, 5770 .

19. http://dionex.su/en-us/webdocs/5050-TN-21-Optimal-SettingsPAD-Carbohydrates-ED40-TN70670-EN.pdf, accessed in March 2018.

20. Iinuma, Y.; Engling, G.; Puxbaum, H.; Herrmann, H.; Atmos. Environ. 2009, 43, 1367.

21. Bauer, H.; Kasper-Giebl, A.; Loflund, M.; Giebl, H.; Hitzenberger, R.; Zibuschka, F.; Puxbaum, H.; Atmos. Res. 2002, 64, 109.

22. Draxler, R. R.; HYSPLIT, version 4.7, National Oceanic and Atmospheric Administration - Air Resources Laboratory (NOAA-ARL), USA, 2004. Available at https://ready.arl.noaa. gov/HYSPLIT.php, accessed in March 2018.

23. CPTEC; CPTEC Monthly 2009 and 2010 Reports, available at www.cptec.inpe.br, accessed in March 2018.

24. Lu, C.; Niu, S.; Tang, L.; Lv, J.; Zhao, L.; Zhu, B.; Atmos. Res. 2010, 97, 47.

25. Błaś, M.; Polkowska, Ż.; Sobik, M.; Klimaszewska, K.; Nowiński, K.; Namiésmik, J.; Atmos. Res. 2010, 95, 455.

26. Forti, M. C.; Moreira-Nordemann, L. M.; Andrade, M. F.; Orsini, C. Q.; Atmos. Environ. 1990, 24B, 355.
27. Souza, S. R.; Vasconcellos, P. C.; Carvalho, L. R. F.; Atmos. Environ. 1999, 33, 2563.

28. Kawamura, K.; Kaplan, I. R.; Environ. Sci. Technol. 1987, 21, 105.

29. Brito, J.; Rizzo, L. V.; Herckes, P.; Vasconcellos, P. C.; Ynoue, R.; Artaxo, P.; Andrade, M. F.; Atmos. Chem. Phys. 2013, 13, 12199.

30. Kerminen, V. M.; J. Aerosp. Sci. 1997, 28, 121.

31. Rastogi, N.; Sarin, M. M.; Atmos. Environ. 2009, 43, 3481.

32. Vasconcellos, P. C.; Souza, D. Z.; Sanchez-Ccoyllo, O.; Bustillos, J. O. V.; Lee, H.; Santos, F. C.; Nascimento, K. H.; Araújo, M. P.; Saarnio, K.; Teinilä, K.; Hillamo, R.; Sci. Total Environ. 2010, 408, 5836.

33. Bauer, H.; Claeys, M.; Vermeylen, R.; Schueller, E.; Weinke, G.; Berger, A.; Puxbaum, H.; Atmos. Environ. 2008, 42, 588.

34. Burstein, N.; Lang-Yona, N.; Rudich, Y.; Atmos. Chem. Phys. 2011, 11, 829 .

35. Fu, P.; Kawamura, K.; Kobayashi, M.; Mochida, M.; Simoneit, B. R. T.; Atmos. Environ. 2012, 55, 234.

36. Chen, S.; Hsieh, L.; Tsai, C.; Fang, G.; Chemosphere 2003, 53, 29.

37. Leal, T. F. M.; Fontenele, A. P. G.; Pedrotti, J. J.; Fornaro, A.; Quim. Nova 2004, 27, 855.

Submitted: November 30, 2017

Published online: April 3, 2018 